\title{
Assessing groundwater vulnerability to sea water intrusion in the coastline of the inner Puck Bay using GALDIT method
}

\author{
Dawid Potrykus ${ }^{1}$, Anna Gumuła-Kawęcka ${ }^{1}$, Beata Jaworska-Szulc ${ }^{1}$, Małgorzata \\ Pruszkowska-Caceres ${ }^{1}$, Adam Szymkiewicz ${ }^{1}$ and L. Dzierzbicka-Głowacka ${ }^{2}$ \\ ${ }^{1}$ Faculty of Civil and Environmental Engineering, Gdańsk University of Technology, \\ Gdańsk, Poland \\ ${ }^{2}$ Physical Oceanography Department, Institute of Oceanology PAS, Powstańców \\ Warszawy 55, 81-712 Sopot, Poland
}

\begin{abstract}
In this research, GALDIT method was used to assess seawater intrusion in the coastal aquifer of the inner Puck Bay (Southern Baltic Sea). The impact of potential sea-level rise on groundwater vulnerability for years 2081-2100 was also considered. The study area was categorized into three classes of vulnerability: low, moderate and high. The most vulnerable area is the Hel Peninsula with northern part of the Kashubian Coastland. Increased class of aquifer vulnerability is also adopted to glacial valleys. The results of this research revealed that about $18.9 \%$ of the analyzed area is highly vulnerable to seawater intrusion, $25.3 \%$ is moderately vulnerable and $55.8 \%$ is potentially at low risk. The simulated scenario of predicted sea level rise shows enlargement of high vulnerability areas.
\end{abstract}

\section{INTRODUCTION}

The deterioration of groundwater resources due to seawater intrusion is a significant problem for the water supply in coastal areas. Seawater intrusion is mostly a result of sea-level rise and groundwater overexploitation that causes coastal aquifers severely vulnerable to salinization. This phenomenon has a degrading influence on the availability of fresh water, ecosystems condition, coastal infrastructure and tourism. Potential implications of sea-level rise for coastline in Poland has been subject of several studies (Pruszak and Zawadzka 2008; Moskalewicz 2016; Paprotny and Terefenko 2017). In order to control seawater intrusion in coastal aquifers, a number of management strategies and prevention methods have been developed (Chachadi and Lobo-Ferreira 2001; Kallioras et al. 2012, Trabelsi et al. 2016). One of the principal approaches to predict the influence of seawater intrusion to groundwater is analysis of vulnerability maps. The most common worldwide method of assessing groundwater vulnerability to seawater intrusion is GALDIT. It is a numerical ranking system, based on six hydrogeological, hydrological and morphological parameters with appropriately assigned weights and ranges (Chachadi and Lobo-Ferreira 2001, 2007; LoboFerreira et al. 2007). The method (or its modifications) has been applied in many coastal regions (Chachadi and Lobo-Ferreira 2007; Louma et al. 2017; Kazakis et al. 2018). In this paper, GALDIT method was used to assess seawater intrusion in the coastal aquifer of the inner Puck Bay (Southern Baltic Sea). The impact of potential sea-level rise to groundwater vulnerability for years 2081-2100 was also considered.

\section{AREA OF STUDY}

The research area is situated along the coastline of the inner Puck Bay, in the eastern part of the Kashubian Coastland and western part $(13 \mathrm{~km})$ of the Hel Peninsula, covering an area of $85,2 \mathrm{~km}^{2}$ (Fig. 1). The vicinity of Baltic Sea creates a specific marine climate in this region, 
which characteristic features are moderate winters and mild summers. The annual temperature is around $7.4^{\circ} \mathrm{C}$ and the average amount of precipitation does not exceed $700 \mathrm{~mm}$. The income of local inhabitants comes mainly from agriculture, fishery and tourism, related to the seaside location and unique environmental values of this region.

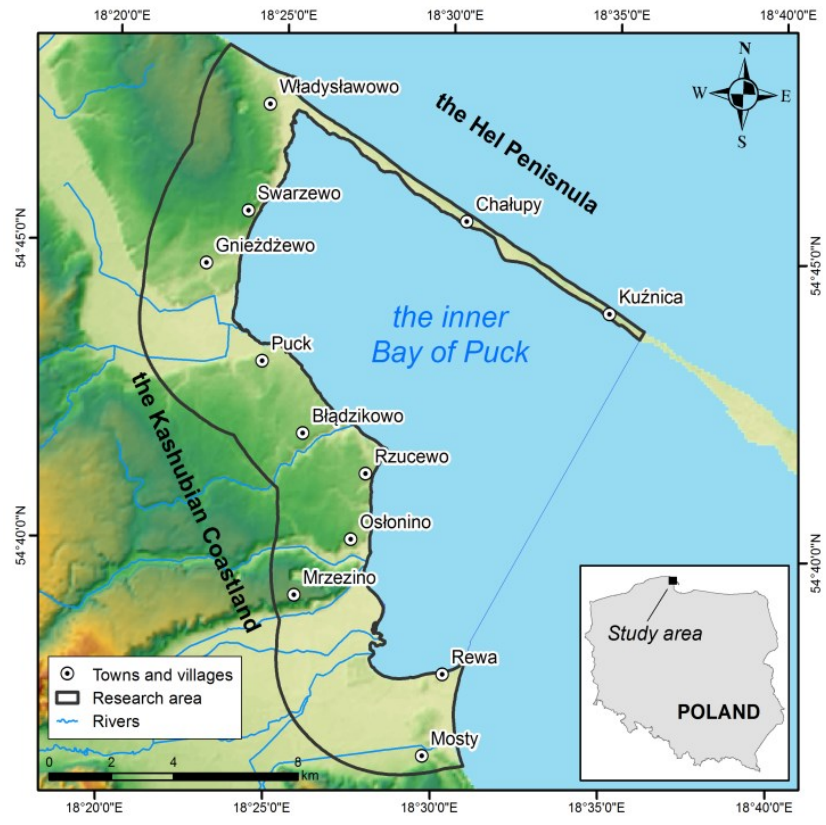

Figure 1. Research area.

The Kashubian Coastland mesoregion has a varying topography, typical for young glacial landscape. Morainic uplands are separated by deeply cut ice marginal valleys. Moraines consist of till deposits, which are divided by series of fluvioglacial sands and gravels. Glacial valleys are covered by extensive peat wetlands and consist of fluvioglacial sediments. The Hel Peninsula was formed during the Holocene under the influence of aeolian and marine processes. This structure is a sandbar, which separates the Puck Bay from the open Baltic Sea. With reference to the coastal system classification (CEUCC), the landscape of Hel Peninsula is a wave-dominated sedimentary plain with dune coasts in microtidal zone (Furmańczyk 2004). Hydrogeological conditions depend mostly on terrain relief and geological setting. In the Kashubian Coastland two aquifers have been identified (Frączek 1998). They consist of fluvioglacial sediments series (sands and gravels) which separate till deposits. Both aquifers are hydraulically connected. In the Hel Peninsula fresh groundwater occurs as a lens in sandy aquifer, which directly overlies pleistocene silty sand sediments. This groundwater cannot be used for water supply, however it is exploited locally and temporally.

\section{APPLIED METHODOLOGY AND MATERIALS}

Assessment of groundwater vulnerability in the studied area has been carried out using GALDIT method. Proposed by Chachadi and Lobo-Ferreira (2001), GALDIT method is a numerical ranking system, based on the most important map-able factors that control the seawater intrusion: $(G)$ groundwater occurrence, $(A)$ aquifer hydraulic conductivity, $(L)$ height of groundwater level above sea level, $(D)$ distance from the shore, $(I)$ impact of existing status of seawater intrusion and $(T)$ thickness of the aquifer. Relative importance of seawater intrusion influence is determined by weight established for each factor and assigned numeric rating, based on its susceptibility to seawater intrusion. The rating and weight values used in calculations are presented in Table 1. Applying the related weight and 
importance rating thematic maps were generated for each GALDIT parameter (Fig. 2). The final map of groundwater vulnerability to seawater intrusion (Fig. 3) was obtained by overlying six weighted maps with the following equation (Chachadi and Lobo-Ferreira 2007):

$$
\text { GALDIT }_{\text {index }}=\frac{\sum_{i=1}^{6}\left(W_{i} \cdot R_{i}\right)}{\sum_{i=1}^{6} W_{i}}
$$

where $W_{i}$ is the weight of the $i$ th indicator and $R_{i}$ is the importance rating of the $i$ th indicator. The final GALDIT index ranges from 2.5 to 10 and is divided into three vulnerability classes: high $(>7.5)$, moderate (5-7.5) and low $(<5)$. Higher values of importance ratings of the variable, corresponds to more vulnerable aquifers to seawater intrusion. Detailed description of GALDIT methodology was presented by Chachadi and Lobo-Ferreira $(2001,2007)$.

Table 1. Summary of GALDIT parameter weight, rates and ranges.

\begin{tabular}{|c|c|c|c|c|c|c|c|}
\hline & & & & & & & \multirow{4}{*}{$=$} \\
\hline Indicator & $G$ & $A$ & $L$ & $D$ & $I$ & $T$ & \\
\hline Weight & 1 & 3 & 4 & 4 & 1 & 2 & \\
\hline Unit & {$[-]$} & {$[\mathrm{m} / \mathrm{d}]$} & {$[\mathrm{m}]$} & {$[\mathrm{m}]$} & [epm] & {$[\mathrm{m}]$} & \\
\hline \multirow{4}{*}{ 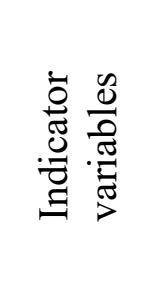 } & Confined Aquifer & $>40$ & $<1.0$ & $<500$ & $>2.0$ & $>10$ & 10 \\
\hline & Unconfined Aquifer & $10-40$ & $\begin{array}{c}1.0- \\
1.5\end{array}$ & $\begin{array}{c}500- \\
750\end{array}$ & $1.5-2.0$ & $7.5-10$ & 7.5 \\
\hline & Leaky confined Aquifer & $5-10$ & $\begin{array}{l}1.5- \\
2.0\end{array}$ & $\begin{array}{l}750- \\
1000\end{array}$ & $1.0-1.5$ & $5-7.5$ & 5 \\
\hline & Bounded Aquifer & $<5$ & $>2.0$ & $>1000$ & $<1.0$ & $<5$ & 2.5 \\
\hline
\end{tabular}

Various multidisciplinary data are required for groundwater vulnerability assessment. The investigation was carried out using data from the Central Hydrogeological Data Bank - The HYDRO Bank of Polish Geological Institute - National Research Institute: 235 boreholes, digital elevation model (DEM) and hydrogeological maps. Spatial distributions of each GALDIT parameter in $3 \mathrm{~km}$ buffer of the inner Puck Bay coastline were integrated with GIS environment and mapped using geostatistical interpolation techniques and GIS analyst tools. Final vulnerability index were estimated by using raster calculator tool.

\section{RESULTS AND DISCUSSION}

Thematic maps of GALDIT parameters obtained for the research area are presented in Fig. 2. Groundwater occurs $(G)$ as confined as well as unconfined aquifers. The hydrogeological system is confined mainly in the upland area and in that part highest vulnerability rank -10 was assigned. Aquifers in the remaining area are unconfined thus in this part rating of 7.5 was applied (Fig. 2-G). The aquifers hydraulic conductivity $(A)$ varies from 6 to $120 \mathrm{~m} / \mathrm{d}$. Therefore, the study area was classified into three classes of vulnerability with ranges $5,7.5$ and 10 (Fig. 2-A). The major part of studied area was rated with 7.5 and locally within upland area with 5 or 10. In reference to the height of groundwater level above mean sea level $(L)$, the considered coastal area was categorized into four classes of vulnerability and rated between 2.5-10 (Fig. 2-L). The lowest values of rating are observed in upland area and increases in discharge area direction (Bay of Puck, open Baltic Sea and glacial valleys). The distance from the shore $(D)$ was estimated according to three distances to the coastline ranges: 500, 750 and $1000 \mathrm{~m}$. The maximum value (10) is assigned for areas situated close to the coast (distance lower than $500 \mathrm{~m}$ ), whereas it decreases as distance inland 
increases (Fig. 2-D). According to poor availability of groundwater quality data it was difficult to reliably estimate impact of existing status of seawater intrusion $(I)$ in entirely area. To evaluate this parameter the ratio of $\mathrm{Cl}^{-} / \mathrm{HCO}_{3}{ }^{-}$(Lobo-Ferreira et al. 2007) were considered instead of recommended Revelle index $\left(\mathrm{Cl} /\left[\mathrm{HCO}_{3}{ }^{-}+\mathrm{CO}_{3}{ }^{2-}\right]\right.$ (Chachadi and Lobo-Ferreira 2007). The impact of parameter $I$ was divided into four classes and rated from 2.5 to 10 (Fig. 2-I). According to the available laboratory analysis the maximum ratio of $\mathrm{Cl}^{-}$ $/ \mathrm{HCO}_{3}{ }^{-}$was observed at the Hel Peninsula and northern part of the Kashubian Coastland. In the major part of the Kashubian Coastland the minimal value was adopted. In terms of the aquifer thickness $(T)$, study area can be divided into two parts. The thickness of aquifer in the Hel Peninsula is $6 \mathrm{~m}$ and it was rated with 5 value, while aquifer thickness in the remaining area is higher than $10 \mathrm{~m}$ and thus it was rated with the highest score (Fig. 2-T).

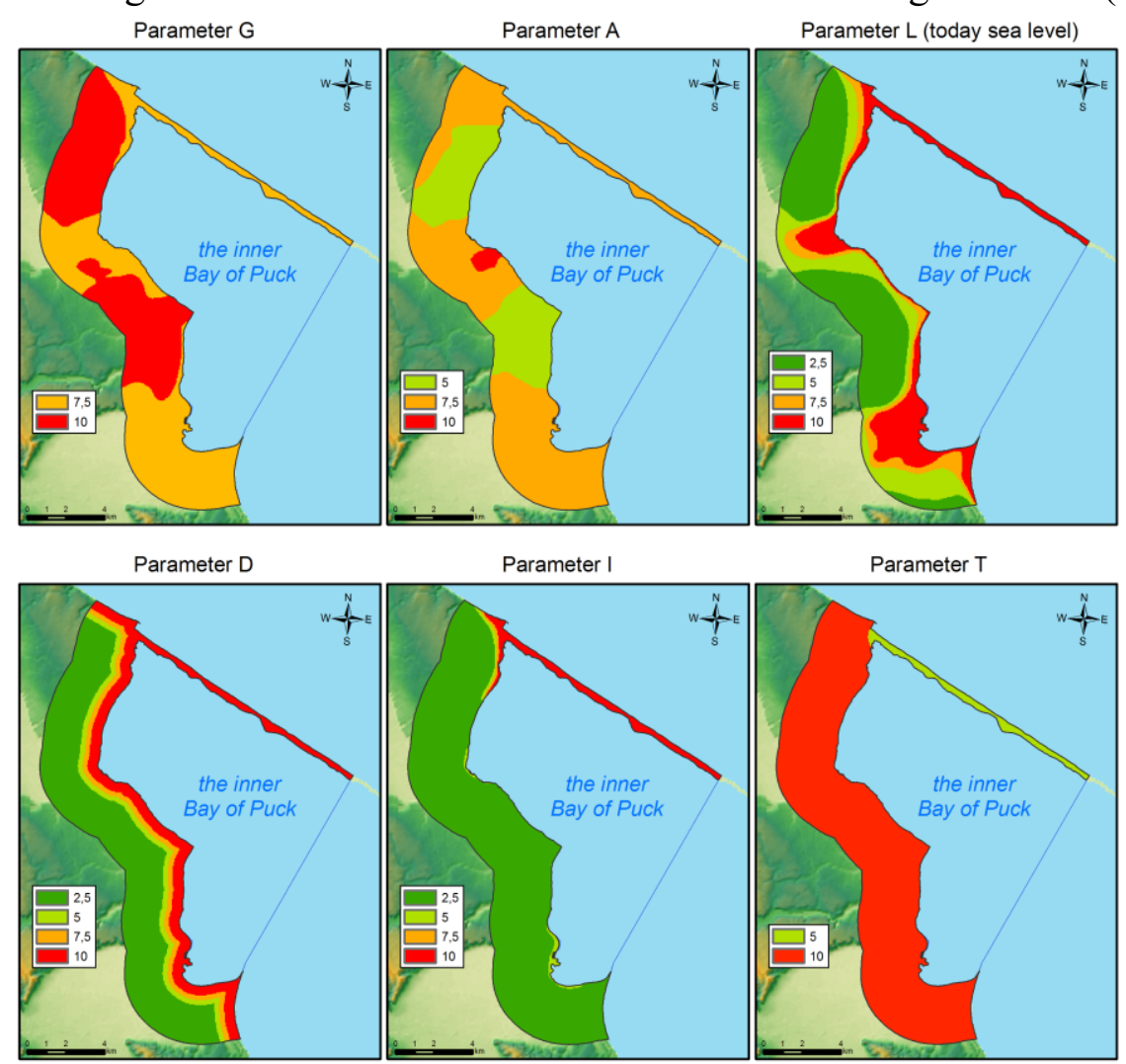

Figure 2. Thematic maps of GALDIT method parameters.

As the Polish coastline is thought to be the most susceptible to sea level rise in Europe (Paprotny and Terefenko 2017) the impact of predicted sea-level rise to groundwater vulnerability was checked. Actual trends of sea level changes may cause increase of coastal aquifers vulnerability to seawater intrusion in the future. Predictions of sea level rise under simulated climate change scenarios for a shallow low-lying coastal aquifer in southern Finland shows that some areas along coastline will be below the seawater level. Together with a coastal flooding, it may expand the saltwater intrusion extension, increasing the pollution of the aquifer with seawater (Luoma et al. 2017). According to the KLIMAT project (Wibig and Jakusik [eds.] 2012), the mean sea level of the inner Puck Bay in the period 2081-2100 is predicted to exceed the current level by $0.28 \mathrm{~m}$ (the most pessimistic scenario). The prediction was estimated based on the greenhouse gases emissions (A2), the impact of circulation factor and expected changes in the global sea level according to the IPCC. The scenario of sea water level rise was included in GALDIT method by decreasing the height of groundwater level above sea level by $0.28 \mathrm{~m}-L$ parameter. The range of the index score was categorized into three classes: $<5,5-7.5$ and $>7.5$, respectively, as low, 
moderate and high. The spatial distribution of GALDIT index in the studied area for the current and raised sea level is illustrated Fig. 3.
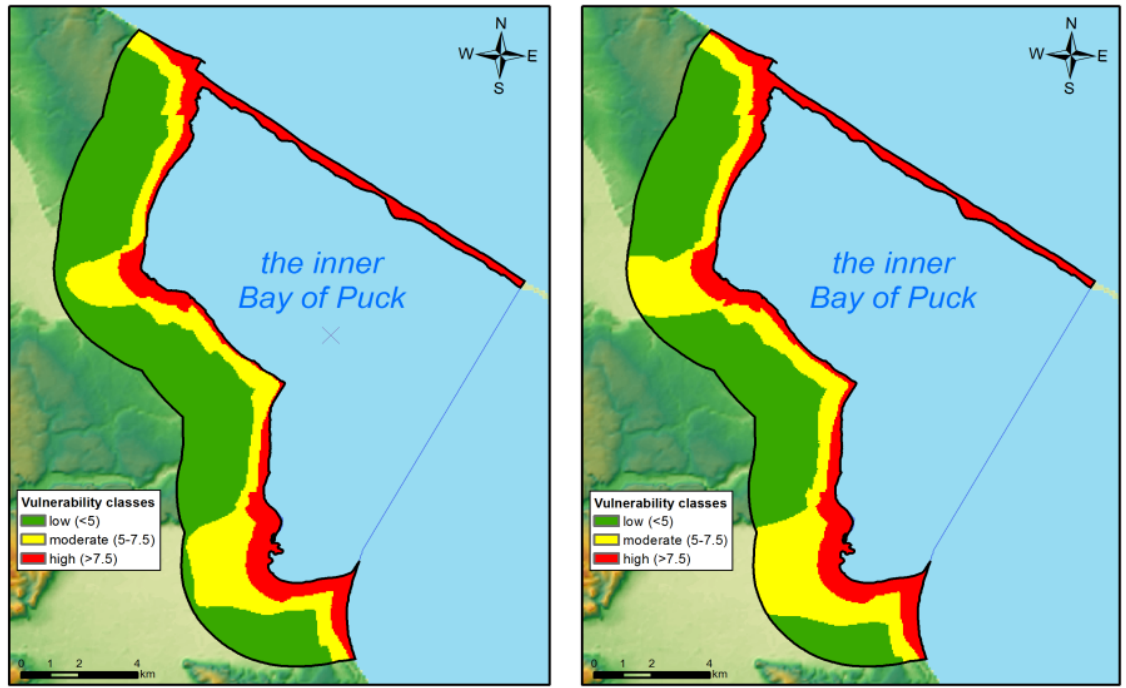

Figure 3. Comparison between GALDIT index for the current and future sea levels (left - current sea level; right-predicted sea level in 2081-2100 years with rise $+0.28 \mathrm{~m}$ ).

The percentage distribution of low, moderate and high vulnerability zones for the current sea level are 55.8, 25.3 and $18.9 \%$, respectively. The simulated scenario of predicted sea level rise shows changes in vulnerable zones percentage distribution, respectively: low $48.7 \%$, moderate $30.5 \%$ and high $20.8 \%$ (Tab. 2).

Table 2. Areal comparison of vulnerability classes.

\begin{tabular}{|c|c|c|c|c|}
\hline \multirow{2}{*}{$\begin{array}{c}\text { Vulnerability } \\
\text { classes }\end{array}$} & \multicolumn{2}{|c|}{ Current sea level } & \multicolumn{2}{c|}{ Predicted sea level in 2081-2100 years $(+0.28 \mathrm{~m})$} \\
\cline { 2 - 5 } & {$\left[\mathrm{km}^{2}\right]$} & {$[\%]$} & {$\left[\mathrm{km}^{2}\right]$} & {$[\%]$} \\
\hline Low & 47.5 & 55.8 & 41.5 & 48.7 \\
\hline Moderate & 21.6 & 25.3 & 26.0 & 30.5 \\
\hline High & 16.1 & 18.9 & 17.7 & 20.8 \\
\hline
\end{tabular}

\section{CONCLUSIONS}

Assessment of the inner Puck Bay coastal aquifer vulnerability to seawater intrusion has been conducted using GALDIT method. The most vulnerable areas are the Hel Peninsula and northern part of the Kashubian Coastland. Increased class of aquifer vulnerability was also obtained for glacial valleys. Differences between actual and future aquifer vulnerability are noticeable. The predicted sea level rise of $0.28 \mathrm{~m}$ in the scenario for period 2081-2100 will increase vulnerability to seawater intrusion on $7 \%$ of the research area. It will be particularly significant in glacial valley areas, where the groundwater table is only slightly above the sea level. The final map of vulnerability can be a useful tool for management of the coastal zone of the inner Puck Bay.

\section{ACKNOWLEDGMENTS}

This work has been supported by National Centre for Research and Development, Poland, in the framework of the project BIOSTRATEG3/343927/3/NCBR/2017 "Modelling of the impact of the agricultural holdings and land-use structure on the quality of inland and coastal waters of the Baltic Sea set up on the example of the Municipality of Puck region - Integrated info-prediction Web Service WaterPUCK" - BIOSTRATEG Programme. 


\section{REFERENCES}

Chachadi A.G. and Lobo-Ferreira J.P. 2001. Sea Water Intrusion Vulnerability Mapping of Aquifers Using GALDIT Method. Proceedings of the Workshop on Modelling in Hydrogeology, Anna University, Chennai, 143-156.

Chachadi, A.G. and Lobo-Ferreira, J.P., 2007. Assessing aquifer vulnerability to seawater intrusion using GALDIT method: part 2, GALDIT indicators description. Water in Celtic Countries Quantity, Quality and Climatic Variability, IAHS Publ. 310, pp. 172-180.

Frączek E. 1998. Hydrogeological Map of Poland 1:50 000 - Puck sheet explanations (in Polish). Polish Institute of Geology.

Furmańczyk K. 2004. Hel Peninsula (Poland). Eurosion Case Study, 28 pp. Available (Feb 2018): http://copranet.projects.eucc-d.de/files/000143_EUROSION_Hel_peninsula.pdf

Kallioras A., Pliakas F-K., Schuth Ch. And Rausch R. 2012. Methods to Countermeasure the Intrusion of Seawater into Coastal Aquifer Systems. In book: Wastewater Reuse and Management (eds. Sharma S.K and Sanghi R.) 479-490.

Kazakis N., Spiliotis M., Voudouris K., Pliakas F-K. and Papadopoulos B. 2018. A fuzzy multicriteria categorization of the GALDIT method to assess seawater intrusion vulnerability of coastal aquifers. Science of the Total Environment 621: 524-534.

Lobo-Ferreira, J.P., Chachadi A.G., Diamantino C. and Henriques M.J. 2007. Assessing aquifer vulnerability to seawater intrusion using GALDIT method: part 1, application to the Portuguese Monte Gordo aqiufer. Water in Celtic Countries Quantity, Quality and Climatic Variability, IAHS Publ. 310, pp. 161-171.

Luoma S., Okkonen J. and Korkka-Niemi, K. 2017. Comparison of the AVI, modified SINTACS and GALDIT vulnerability methods under future climate-change scenarios for a shallow low-lying coastal aquifer in southern Finland. Hydrogeology Journal v. 25:1 203-222.

Moskalewicz D. 2016. Hel Peninsula - development and future of sandy barrier under sea level rise. In book: Quaternary geology of north-central Poland: from the Baltic coast to the LGM limit (eds. Sokołowski R.J. and Moskalewicz D.) 5-16.

Paprotny D. and Terefenko P. 2017. New estimates of potential impacts of sea level rise and coastal floods in Poland. Natural Hazards v. 85:2 1249-1277.

Pruszak Z. and Zawadzka E. 2008. Potential Implications of Sea-Level Rise for Poland. Journal of Coastal Research v. 24:2 410-422.

Trabelsi N., Triki I., Hentati I. and Zairi M. 2016. Aquifer vulnerability and seawater intrusion risk

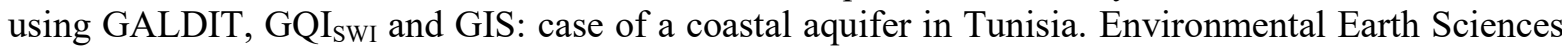
75:669

Wibig J. and Jakusik E. (eds.) 2012. Warunki klimatyczne i oceanograficzne w Polsce i na Bałtyku południowym (in Polish). Institute of Meteorology and Water Management - National Research Institute. Available (Feb 2018): http://klimat.imgw.pl/wp-content/uploads/2013/01/tom1.pdf?edmc=

Contact Information: Dawid Potrykus, Gdańsk University of Technology, Faculty of Civil and Environmental Engineering, 80-233 Gdańsk, ul. Narutowicza 11/12, Poland, Phone: +48 583472311 Email: dawpotry@pg.edu.pl 